\title{
Teachers' Perceptions about Leadership: Towards an Innovative Collaborative Teacher Leadership Development Framework for Schools
}

\author{
Edwin Darrell De Klerk* \\ Sol Plaatje University, Kimberley, South Africa \\ Natalie Jane Pauline Smith \\ Sol Plaatje University, Kimberley, South Africa
}

\begin{abstract}
The development of the literature on teacher leadership in the academic realm has been exponential, but the quest for more leadership knowledge seems to be inexhaustible. The purpose of this paper is to analyze teachers' perceptions with respect to their leadership abilities. Email interviews were conducted with nine teachers from two primary and two secondary schools to obtain their views regarding teacher leadership, whilst affording them opportunities to make suggestions for collaborative teacher leadership development. Having employed a phenomenological approach and thematic analysis as method, this paper proposes a collaborative teacher leadership development framework (CTLDF). Significant about the CTLDF is that teacher leaders should consider ausgang as a way of opening the door for collaboration, homo economicus as a collaborative act and parrhesia as autonomy towards collaborative teacher leadership. The findings reveal that teacher leaders should cultivate a readiness to create opportunities for collaborative leadership development. The study recommends that teacher leaders should first have to be cognizant about their own individual strengths, whilst slowly starting initiatives to collaborate in order to sustain improvements in teacher leadership practices.
\end{abstract}

Keywords: ausgang; collaborative teacher leadership; homo economicus; parrhesia; teacher leaders

\section{Introduction}

Whilst many teachers live with idealistic imperatives to "be one's own person and to give expression to one's individual philosophy" (Case et al., 2011, p. 686), the COVID-19 pandemic has required teacher leaders to seize opportunities to

\footnotetext{
* Corresponding author: Edwin Darrell de Klerk, darrell.deklerk@nwu.ac.za
} 
perform their day-to-day work more skillfully. Importantly, the perception of leadership has become so significant that it is nearly impossible to study the past and the present without seeing leaders and leadership everywhere. Thus, although much research has been conducted regarding leadership development, COVID-19 has required a change in the way individuals speak or write about teacher leadership - from one subjugated interpretation of leadership toward a deeper understanding of concepts thereof. In this paper, the focus has shifted from meanings about leadership to that of teacher leadership development because we believe that schools should be "poised to help teachers to be the beacon of light" (Behrstock-Sherratt et al., 2020, p. 1). The shift of focus is significant because teachers should "be empowered to be actors of change" (Organisation for Economic Co-operation and Development, 2020, pp. 3-4) during and beyond the COVID-19 pandemic. Notably, the current crisis has created opportunities to uplift teacher leaders, whilst celebrating and recognizing the extraordinary leadership teachers are exhibiting.

Beyond the dispositions, skills and knowledge exemplified by teacher leaders, they should epitomize a movement-in-action to promote the teaching occupation into a respected profession. The indication of "movement-in action" can be associated with a view by Zhang et al. (2021) who postulate that to develop teachers' leadership skills, thought and time should be invested to follow a collaborative approach. The aforementioned statement is significant because collaborative leadership advances through the practice of influencing teachers and engendering proficiency through collaboration (Zhang et al., 2021). In their dissertation on teacher leadership development, Gratacós et al. (2021) aimed to develop an understanding of teacher leadership as portrayed in official documents in Spain. The appraisal of those documents exposed an inadequate appreciation of the significance of teacher leadership. Their results suggested that there is a need to further develop teacher leaders as a consequence of changing circumstances experienced by the teaching profession. In another paper, Mitchell (2021) focused on developing teacher leadership during unprecedented times of change. The aim of Mitchell's (2021) paper was to acquire more information regarding the development and growth of teacher leaders in Kansas during the 2020-2021 COVID-19 pandemic. The findings revealed that during times like COVID-19, increased opportunities exist for teacher leadership development. The paper recommended that leadership development should be versed in learning styles that foster collaboration in an attempt to grow teachers' collective efficacy (Mitchell, 2021).

Apart from research that focused on teacher leadership, we regard it as significant to provide a synopsis of a few teacher leadership development frameworks already in the public domain (Table 1). 
Table 1: Teacher Leadership Development Frameworks in the Public Domain

\begin{tabular}{|l|c|l|l|}
\hline \multicolumn{1}{|c|}{ Author(s) } & $\begin{array}{c}\text { Year of } \\
\text { publication }\end{array}$ & $\begin{array}{l}\text { Teacher leadership } \\
\text { development } \\
\text { framework }\end{array}$ & $\begin{array}{c}\text { Core aspects of teacher } \\
\text { leadership development } \\
\text { framework }\end{array}$ \\
\hline Angelle & 2017 & $\begin{array}{l}\text { Four-factor model } \\
\text { of teacher } \\
\text { leadership }\end{array}$ & $\begin{array}{l}\text { The role of teachers outside } \\
\text { the classroom, expertise and } \\
\text { roles in instructional } \\
\text { practices, } \\
\text { independence/enablement, } \\
\text { collaboration as well as } \\
\text { participation and engagement }\end{array}$ \\
\hline Cheung et al. & 2018 & $\begin{array}{l}\text { Defining teacher } \\
\text { leadership: A } \\
\text { framework }\end{array}$ & $\begin{array}{l}\text { Collaboration, } \\
\text { encouragement, modelling } \\
\text { and availability of resources }\end{array}$ \\
\hline $\begin{array}{l}\text { Berg \& } \\
\text { Zoellick }\end{array}$ & 2019 & $\begin{array}{l}\text { Teacher leadership: } \\
\text { toward a new } \\
\text { conceptual } \\
\text { framework }\end{array}$ & $\begin{array}{l}\text { Legitimacy, support, objective } \\
\text { and method }\end{array}$ \\
\hline
\end{tabular}

The aforementioned frameworks aimed at addressing ambiguities in meaning regarding teacher leadership, whilst advocating for more knowledge in this field. Our paper adheres to the call for further research on teacher leadership development in unprecedented times like the COVID-19 pandemic. It is similar to the aforementioned studies in that the notion of collaboration in terms of teacher leadership development is strongly foregrounded. It is different in that we are drawing on the views of South African teachers in four schools in the Northern Cape province of South Africa to propose a collaborative teacher leadership development framework (CTLDF). By analyzing the views of teachers, we "share the stories and voices of everyday teachers who take a social justice stance and act on it" (Baker-Doyle, 2017, p. 8). In so doing, a CTLDF may assist teacher leaders to keep track of changes and developments regarding teacher leadership in schools.

\section{Literature Review}

\subsection{Changing the mind-set about teacher leadership development amid COVID-19}

Individuals construct their social reality in ways that reflect and reinforce their mind-sets (Gergen, 2015), and the mindfulness of such potential can be an influential power for developing their sense of fulfilment (McGonigal, 2015). Notably, mind-sets are core sets of beliefs that become the lenses through which individuals appreciate, understand, and reply to the world within which they live and work (Gergen, 2015). The more individuals see the world as an opportunity to develop, the more they seem to find opportunities for development to happen. This implies that the more schools allow for a mind-set change regarding teacher leadership, the more teachers would develop capacities for personal growth, which is an important contributor to leadership development. Furthermore, the notion of teacher leadership development suggests that teachers may become more aware of who they are and how they can be showing up at work in a more authentic way (Drago-Severson \& Blum-DeStefano, 2018). Thus, as teacher 
leaders gain more confidence, they can start to shift the lens toward their colleagues and provide encouragement and support for them as they engage in collective growth in schools.

COVID-19 has required teachers to change their taken-for-granted frames of reference (mind-sets). Significant about a change regarding frames of reference is that teacher leaders are required to become "more inclusive, discriminating, open, emotionally capable of change, and reflective so that they may generate beliefs and opinions that will prove more true or justified to guide action" (Mezirow, 2000, p. 8). To illustrate, COVID-19 has opened opportunities for "teachers to be trained how to lead with self-awareness and self-regulation", "schools to allow teachers to lead changes" and "teachers to give meaning to changes through descriptions, feelings and expectations" (De Klerk \& Smith, 2021, p. 62). Interpreting the view of De Klerk and Smith (2021, p. 62), teacher leadership development should be thought of as a process of empowering teachers to achieve what they believe is worth achieving and what they want to achieve in future.

Consequently, teacher leadership development should be understood to be at the center of changing "values into actions, visions into realities, obstacles into innovations, separateness into solidarity, and risks into rewards" (Smith \& Riley, 2012, p. 57). In this regard, teacher leadership development should be about teachers getting opportunities to live their potential and worth so that they can see leadership in themselves, whilst unleashing such potential in those around them.

\subsection{Collaborative teacher leadership as transformative learning experience}

One of the main elements for successful collaborative action in teacher development is that there should be a demonstration of intellectual and emotional ripeness, aiming at a mind-set change to allow teachers to become more eager to deal with and to solve challenges in schools (Vicente et al., 2018). Arguably, collaborative intellectual efforts in terms of teacher leadership may be considered as a mutual knowledge practice in which all teachers are involved in combining thinking about leadership in an inventive way. This implies that collaborative teacher leadership has an unlimited possibility to yield collaborative affiliations where individuals share challenges and opportunities and, in so doing, ease the responsibility of teachers to attain enhanced leadership performance (Pasetto et al., 2021).

Despite unlimited possibilities, collaborative teacher leadership development seems not to be without any challenges. Firstly, teacher leadership has yet to take an official position in schools' administration because teacher leaders' unclear standing may encourage skepticism on the part of colleagues, thus encumbering collaboration (Johnson, 2019). Secondly, teacher leaders may experience hostility from their colleagues and the aspiration for additional and profounder collaboration could be perceived negatively by their colleagues (Landa \& Donaldson, 2020). Notwithstanding these limitations, COVID-19 has brought new opportunities to rethink collaborative teacher leadership. Our argument resonates 
with the thought that "teacher leadership recognizes teachers' instructional expertise as an asset for educational improvement, capitalizes upon teachers' relationships with their colleagues to support change, and may provide career advancement opportunities to improve job satisfaction and the professionalization of teaching" (Berg et al., 2019, p. 3). Based on Berg et al.'s (2019) assertion, more opportunities for collaborative teacher leadership development may be a worthwhile transformative learning experience in schools.

To ensure that teacher leadership development becomes a transformative learning experience, "a high degree of trust will be needed, as the collective glue, to ensure that issues are addressed collectively as they arise" (Harris \& Jones, 2020, p. 246). This statement implies that teacher leaders, when working collaboratively, should first transform problematic mind-sets (expectations and assumptions) about leadership by making it more emotional, thoughtful and open to change. Thus, in an endeavor to make collaboration worthwhile, teacher leaders should consider assessing their assumptions, exploring options for new roles, action and relationships as well as finding transformative ways to nurture new roles and relationships (Mezirow, 2011). In this instance, teacher leaders should guard against superficial collaboration by deliberately making an effort to understand their roles and how they project themselves to others. Arguably, transformative learning in terms of collaborative teacher leadership should be an organized effort to assist colleagues to enhance their dispositions, understanding and skills (Mezirow, 2012) as to what the role of teacher leaders should be. In so doing, collaborative teacher leadership may encourage individuals to become more autonomous, creative, self-reflective and inclusive.

\subsection{Reasons for rethinking collaborative teacher leadership amid COVID-19}

The potential and possibility of teacher leadership are regarded as a fundamental matter within the global dialogue about educational change and reform because the manner in which teachers contribute to transformation, and dynamically contribute towards leading transformation, has been demonstrated to be significant to the attainment of any development effort. In this regard, COVID-19 has required that in order to lead change, there should be a move from working in silos and new emphasis should be placed on working collaboratively in schools (Education Development Trust, 2020a). We, like Harris and Jones (2019, p. 125), argue that teacher leaders who work collaboratively are individuals who will do "amazing things; they will initiate, innovate, implement and share a wide range of projects which can develop collaborative professional learning, improve practice and support student learning." When teacher leaders are thus afforded opportunities to move out of their comfort zones, they may be positioned to think differently, whilst reimagining what a more equitable, resilient and effective school environment might look like.

Furthermore, it has become imperative to investigate how leadership is presently developing, whilst it has become more significant for teachers to be willing to participate in leadership development. It should also be considered that innovative collaboration methods can create ideal spaces where teachers can learn how to strengthen their ability to provide quality education for all (Education Development Trust, 2020b). Significantly, collaboration between teacher leaders 
can facilitate more universal methodologies to education developments and provide heightened connection and endless progress. As it has become more significant to build durable relationships and, when working collaboratively, teacher leaders should have a new awareness of their experiences inside the self (their mind-set), whilst paying attention to what is happening around them (Wilson, 2021). In so doing, they may be able to cultivate new habits of mind which is a fundamental disposition to develop during collaboration in schools. Such habits include "being aware of and reflecting on current, present, and past experiences in a non-judgmental manner, demonstrating flexibility and appropriate responsiveness when problem solving, resiliency during difficult times, and demonstrating empathy and compassion towards others" (Wilson, 2021, p. 7).

As the role of school leaders has become a more demanding duty, this paper supports the need for understanding collaborative teacher leadership amid COVID-19, which may be significant for future leadership development in schools. We argue that teacher leaders who want to make an effort to work collaboratively should demonstrate a growth mind-set towards building positive relationships with colleagues, learners and the entire school community. Notably, rethinking teacher leadership is influential because of its ability to develop teachers' self-esteem and value of their functioning through better commitment and collaboration (Kamaruzaman et al., 2020).

\section{Research methodology}

We employed a phenomenological approach in this paper to hear and interpret the different perceptions of teachers in their unique school contexts. By sharing their perceptions of how their leadership qualities were developed, teachers could re-experience the positive emotions of thinking differently, of assisting, of rethinking established ways of doing and, in so doing, reflect on how they actually developed and applied leadership qualities (Clandinin \& Connelly, 2000). The sharing of perceptions aligns with phenomenology because it assists in identifying phenomena as perceived by participants in a particular setting (Lester, 1999). Thus, researchers are able to gather rich information and perceptions through qualitative methods such as interviews. By having afforded the participants an opportunity to share their perceptions, we were able to propose an innovative collaborative teacher leadership framework for future collaboration among teachers in schools.

A phenomenological approach was effective in bringing to the fore the perceptions of teachers from their own perspectives (Lester, 1999). The use of phenomenology was appropriate because were afforded opportunities to provide detailed interpretations and descriptions of the participants' lived experiences through bracketing (Qutoshi, 2018). The use of bracketing in phenomenology is significant for research to gain insights into lived experiences. According to Speziale and Carpenter (2007), bracketing is an effective way to ensure validity of the collection and analysis of data. The connection between teachers' perceptions as well as the environments they found themselves in were highlighted. An application of phenomenology enabled us to obtain valuable information and to 
present findings with a more in-depth understanding about collaborative teacher leadership amid COVID-19. We, therefore, delved deep into the perceptions of the teachers to bring to the fore the rich, underlying tenets of collaborative teacher leadership. We hold the view that the knowledge gained may offer the reader an innovative understanding of the phenomenon under study and extra insight so that it can be applied to different school contexts.

\section{Applying social constructivism as theoretical lens}

This paper was supported by a social-constructivist theory (SCT) because it involved the application of interpretive and naturalistic methods to interpret and intelligently think about phenomena in terms of understandings individuals assign to them (Pouliot, 2007). Human consciousness is seen as the result of a person's social connections with significant persons (Kozulin, 1990). Individuals' perceptions of reality are linked to their experiences which, in turn, are linked to individual communication in the social context. At the same time, the way in which individuals describe the social world has an impact on meaning creation because their interactions add to information about others and the creation of new knowledge. An application of social constructivism in this paper can thus be deemed relevant because teachers were afforded opportunities to share their perceptions about their involvement in collaborative efforts regarding teacher leadership amid COVID-19. Notably, nine participants from four different schools in the Pixley Ka Seme (PKS) district of the Northern Cape province in South Africa expressed their views on how they understood their own roles as teacher leaders, whilst starting to work towards collaborating with colleagues.

We were cognizant that socially constructed realities should be regarded as ongoing because individuals act according to their own understanding of things (Thomas et al., 2014). Our focus was thus on the participants' learning which took place because of their collaborations within a specific environment, that is, teacher leadership amid COVID-19. Social constructivism is thus a theory of learning that deals with the attainment of information regarding the lived experiences of individuals (Mogashoa, 2014). Of significance to this paper is the notion that social constructivism promotes problem solving and collaboration in order to construct meaningful knowledge.

\section{Sampling and data collection tools}

This paper is the third research study that is part of a research project undertaken in Douglas schools in the Northern Cape province of South Africa. Douglas is a rural and agricultural town located close to the confluence of the Vaal and Orange Rivers. We visited four schools in Douglas to discuss our research projects with teachers and senior management team members. For this study, we purposively selected nine teachers, representing four schools (two primary and two secondary schools), to tell their stories about teacher leadership amid the COVID-19 pandemic. The selection of participants for this study was based on the view of Yin (2011) who claims that selected participants can bring richness and relevance of information in relation to a study's research questions. Information-rich cases are those from which we can collect extensive data about the central matters of 
collaborative teacher leadership because such cases yield insights and in-depth understanding (Patton, 2015).

We made use of email interviews to enable participants to share their perceptions about teacher leadership during the COVID-19 pandemic because email can be effectively used when conducting in-depth interviews (Meho, 2006) to generate rich qualitative data (Costello et al., 2017). Researchers are thus in a position to explore the thoughts, beliefs and feelings of the participants, whilst allowing individuals to identify those issues that have personal significance and meaning to them (Taylor, 1989, p. 52). Thus, using email interviews to capture the perceptions of the participants was more than just "look for and hear story" (Clandinin \& Connelly, 2000, p. 78). Rather, the use of email interviews enabled the teachers' involvement, and its asynchronicity made it easy for them to build storylines at a speed suitable to them, contrasting the controlled space and time they might have experienced in a telephonic or face-to-face interview (James, 2016). Email interviews offered the participants an approach of communication that give the selected participants the opportunity to consider their answers (Illingworth, 2006). Interestingly, our participants took the opportunity to think and talk about information regarding collaborative teacher leadership that might otherwise have continued to be silent and imperceptible. We, therefore, argue that email interviews were potentially enabling because they allowed participants to be in control of where, how and when they wanted to respond to the questions (Bowker \& Tuffin, 2004). On the other hand, email interviews may equally be regarded as frustrating for researchers because of a lack of power over the sequential course of interviews. Fortunately, we agreed that our participants would respond to the email interview in their own time, allowing them to take authority of the process of sharing their perceptions regarding teacher leadership. Notably, the participants were eager to complete the email interviews and responded to us within a short period of time.

Email interviews were useful, especially during the COVID-19 pandemic, because asynchronous email interviewing allows continued engagement with research and provides participants with time to collect and articulate their thoughts, while concurrently ensuring the safety of both participants and researchers (Amri et al., 2021). On receipt of responses, participants were immediately de-identified, the responses were transferred to individual word documents (each with its own encryption codes) to ensure safety of the data. We then sorted the data before starting our process of analysis.

\section{Data analysis}

We employed thematic analysis to analyze the perceptions of the participants. We were aware that while generating themes based on research data, thematic analysis was flexible, which could lead to inconsistency and contradiction (Holloway \& Todres, 2003). To address the aforementioned disadvantage of thematic analysis, we kept records of the raw data which assisted us to systemize, relate, and cross-reference data (Halpren, 1983). This also helped to create a clear audit trail of the data we would be using. In this paper, thematic analysis helped to contextualize data, whilst it gave "the dimension of realism, authenticity, 
humanity, personality, emotions, views and values in a situation" (Chikoko, 2015, p. 91). Our analysis involved a summary of the data in terms of similar words, expressions, patterns or themes. We started by organizing and preparing the data. Data were organized into stories for each participant. In so doing, we were able to become acquainted with the data. According to Nieuwenhuis (2017), a worthy analysis depends on an understanding of the data. During this step, we transferred the content of the email interviews and summarized participants' perceptions in their own words. The participants were indicated as T01 to T09, implying that there was nothing that could potentially make them identifiable. We read the data again and kept reflective notes which helped us to analytically consider insights and ideas as patterns became visible from the data (Pandey \& Pandey, 2015). The coding procedure was the third stage in which the data was coded manually. Coding is defined as, "the process of reading carefully through your transcribed data, line by line, and dividing it into meaningful analytical units ... as marking the segments of data symbols, descriptive words or unique identifying names" (Nieuwenhuis, 2017, p. 116). We reviewed and re-read the narratives and took cognizance of all repetitive views, thoughts, and patterns. Guided by the aim of this paper, we recovered and produced all the codes that could be connected with teachers' views regarding collaborative teacher leadership amid COVID-19. We coded repetitive words and fundamental words with the aim of grouping and linking trails for an easy interpretation of the data. We then categorized codes into a structure by building a main code list that helped us in making sense of the data (Nieuwenhuis, 2017). Codes were positioned into reliable groups and, for this paper, the nine teachers' views which represented the codes the best, were grouped together for analysis. The codes were reduced to three main themes, namely: ausgang as a way of opening the door for collaboration; homo economicus as a collaborative act; and parrhesia as autonomy towards collaborative teacher leadership.

\section{Findings and discussion}

To present the findings, we used codes T01 to T09 to recognize the participants. Significantly, the results align with contemporary research concerning the influence of COVID-19 on educational matters such as collaborative teacher leadership development. We, henceforth, propose the following culturally responsive leadership framework (CRLF) in support of our findings and subsequent discussion (Figure 1): 


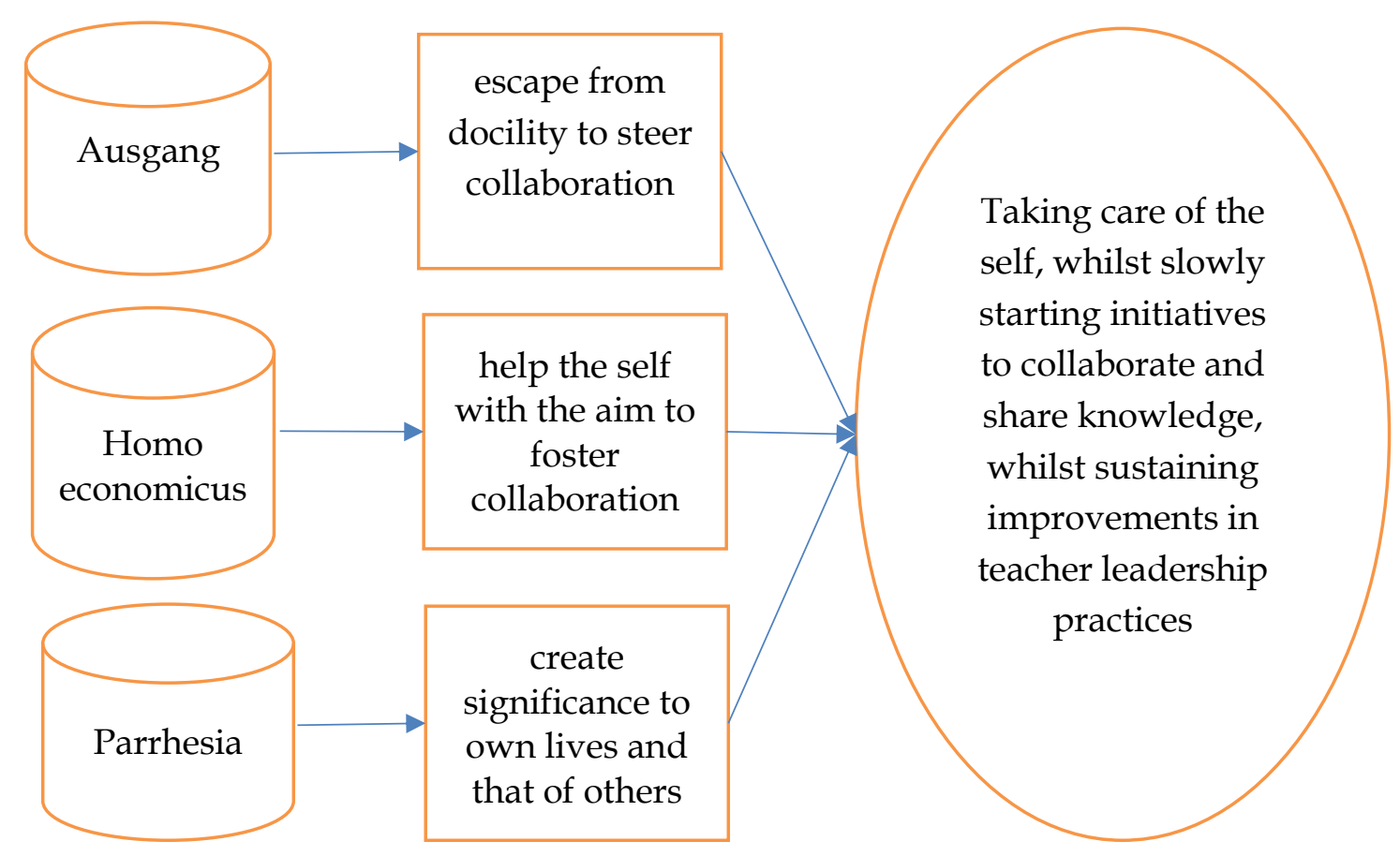

Figure 1: Collaborative teacher leadership development framework (CTLDF)

\subsection{Ausgang as a way of opening the door for collaboration}

COVID-19 has required teacher leaders to search for new meaning and purpose, an urge to become less docile, whilst reclaiming a connection with others in a significant manner. In such instance, teacher leaders may be looking for "an exit" or "a way out" (ausgang), taking a microscopic look at the roles they need to play to bring meaning to the school environment (De Klerk, 2014). We argue that ausgang (an exit or a way out) refers to teacher leaders' ability to choose what actions are suitable to lead and then carry out those actions in an autonomous way. The three teachers (T01-T03) whose responses best represented views regarding ausgang, to escape from docility in their schools during COVID-19, responded as follows:

"Teacher leaders should create a positive a learning environment for children to flourish in his own capacity, making it possible for a child to develop as an individual. Teacher leaders must be able to take charge, they have to step up and be extra vigilant. I am of opinion that whilst taking steps to improve the situation at school, we must find ways to work together with other teachers to set an example and to reach particular goals." [T01]

"I think that one should earn respect by starting to take charge of the challenges that we are facing. One can for instance start by being focused on the task at hand and then be available when others need you. I also think that it is important to start a supporting group to start working on a healthy learning environment which will be beneficial to all in future." [T02]

"Like in any business, the school is also a place where someone should take lead of things, to organize and to assist others. I think a way to start to be 
a leader is to be assertive in terms of what you want to do, to work with enthusiasm. Teacher leaders should then, when they take charge of themselves, strengthen the hands of other so that everybody can contribute to changes. So, from growing as an individual and then growing together is definitely something worthwhile to ensure a brighter future for the school environment, albeit challenges like the COVID-19 pandemic." [T03]

In terms of ausgang, indications such as "should create", "take charge", "step up" and "to start" signify that teachers have mastered knowledge about themselves and the meanings regarding teacher leadership. This implies that teacher leaders should take a stance to move away from the confines that a pandemic like COVID19 may bring. By making use of ausgang, teacher leaders would position themselves to take responsibility for who they are and what they can do. Arguably, if teacher leaders would examine their personal capacities, promote a mindfulness of their professional confines, but apply their minds, they would be able to move beyond the boundaries of any pandemic. By taking charge of the self, they may then be in a position to work in collaboration with others. This aligns with the literature review in this paper in that COVID-19 has encouraged teacher leaders to step up to become more inclusive, perceptive, vulnerable, sensitively capable of transformation, and thoughtful so that they may guide themselves whilst planning towards working collaboratively with others. At the same time this aligns with the theoretical framework in that the participants described the realities regarding their ausgang during COVID-19 and how they interacted with others towards stronger collaborative leadership in future.

\subsection{Homo economicus as collaborative act}

Drawing on De Klerk (2014), homo economicus refers to free and autonomous beings who use opportunities to learn about the veiled self, to take care of the self and then to free the self from educational challenges that may arise. During such discovery, the homo economicus is regarded as an entrepreneur, an individual capable and responsible for taking care of the self. Thus, teacher leaders have to learn that to take a leap of faith may be significant in achieving sharper focus and effectiveness. The teachers (T04-T06) whose views could be closely aligned with the notion of homo economicus, are noted:

"A teacher leader should take the lead in first and be an example and together with that is to make well-planned decisions. To help the self, teachers should participate in professional learning activities. Although my leadership role in our school is relatively small, I still regard it as important. I also collaborate and make plans for specific interventions and to give support and help." [T04]

"I regard it as important to have an idea what it is to help myself and how to grow before I can actually be of assistance to others. I think this is important because teacher leaders should have great leader qualities and an excellent work etiquette. We will then be able to serve others, see their needs and challenges and do something about it. This is what I call helping the self to help other." [T05] 
"I want to start off to say that every teacher is a leader in their own class. Teachers should show their individual strength in the way they showcase their skills. To help yourself, teachers should be obliged to attend a leadership course, even if it is only to understand what leadership entails. During COVID-19 I argued that leaders should set the example to be in control of the self, whilst motivating others - this is a great way to ensure good collaboration with teachers in future. In so doing, I help myself and others to understand our shortcoming while working on improving ourselves." [T06]

The homo economicus takes care of the self and, derived from the participants' responses, phrases like "lead in first", "helping the self" and "control of the self" are clear examples of self-care. Arguably, when teacher leaders want to exercise self-care, they should question their own actions, interrogate their educational beliefs and objectives which would guide them as to what they should do and, consequently, what they should learn to lead from their experiences. In so doing, teacher leaders would deliberately assess their beliefs and explore ways to improve individual abilities, whilst finding transformative ways to nurture new roles and relationships. This may result in teachers becoming more approachable in terms of efforts to communicate, collaborative preparation as well as taking responsibility for contemporary leadership abilities to help the self, whilst creating opportunities towards collaborative growth. This aligns with the theoretical framework in this paper in that individuals should consider the thought that socially constructed realities should be regarded as ongoing, and individuals should, therefore, act on their interpretation and knowledge in terms of teacher leadership development.

\subsection{Parrhesia as autonomy towards collaborative teacher leadership}

The purpose of parrhesia, besides directing oneself in an open and free manner, is to foster the construction of a contemporary and analytically thoughtful self (Foucault, 1983). When aligned with the COVID-19 pandemic, the aim of such construction would be to circumvent being held as a slave of the situation individuals find themselves in, but rather to attain mastery over the regulations posed upon them. The participants (T07-T09) expressed themselves in the following way:

"In collaborating with other colleagues at the schools, may contribute to improvements becoming a reality. One should be goal-oriented, taking small steps at a time. One should, therefore, take a stance to be in control of your own practices and development - this will make it easier to work together with other colleagues." [T07]

"Teacher leaders should have courage, integrity, passion, positive attitude and a lot of commitment. They should draw on their individual strengths and abilities. In this way, helping one another, we can all grow professionally." [T08]

"Development of the self and others is very important. Remember, a motivated teacher is crucial to success in the classroom. I believe that teacher leaders who are in control of their practices, will also be able to 
share different teaching approaches, encourage each other to attend workshops based on teacher development and work as a team." [T09]

The participants' responses reveal that they regard "an autonomous self" as important for teacher leadership development, whilst they also seemed to be prepared to work towards collaborating with colleagues. This is echoed in phrases such as "in control of your own practices", "draw on their individual strengths" and "development of the self and others". Arguably, to act on the notion of parrhesia, teacher leaders may become the authors of their individual leadership capacities and understandings where they create meaning in their personal lives and those of others without weakening the locus of the individual self. From the literature review in this paper it can be derived that autonomy is motivated by a necessity for individual and professional development, so that self-directed teacher leaders may seek out opportunities over the course of their careers to develop further, whilst being more ready to collaborate with others. This aligns with the theoretical framework in this paper in that teacher leaders were afforded the opportunity to describe their leadership abilities amid COVID-19 and how it has impacted on meaning creation because their interactions added to information about themselves and how they would like to see collaboration with others.

\section{Conclusion}

The purpose of this paper was to analyze teacher perceptions with respect to their leadership abilities amid the COVID-19 pandemic, whilst also making suggestions for collaborative teacher leadership development. In lieu of an analysis of participants' narratives, a CTLDF was proposed. The framework recommends that teacher leaders, in their endeavor to improve their leadership abilities, also make room for collaborative teacher leadership in future. Firstly, ausgang urges a move out of a state of docility to a deliberate effort to act upon the desire to collaborate with others to improve leadership in schools. Secondly, homo economicus suggests that teacher leaders should be innovative and responsive, whilst creating opportunities for collaborative growth. Thirdly, parrhesia notes that the teacher leaders should acknowledge that working towards collaboration may be a process and, therefore, they must prepare themselves to effectively collaborate with others.

This paper supports earlier findings in the academic literature. For instance, Fairman and Mackenzie (2014) have discussed the significance of relationships, collaboration, collegiality and trust in supporting teacher leaders; development and school improvement. Their findings revealed that teacher leaders who perform duties as teacher leaders rarely saw their work as significant, whilst they acknowledged that working collaboratively had a greater impact on school improvement. Complementary to the aforementioned study, our study contributes to knowledge in that it proposes a CTLDF with innovative strategies which have not yet been associated with future teacher leadership development. Arguably, the CTLDF provides thoughts to accelerate progress in terms of collaborative teacher leadership development, whilst it foregrounds teacher leaders' authority regarding collaborative efforts for professional growth. 


\section{Limitations}

Although this paper is the third of a series as part of a research project at a university in South Africa, it only captured the narratives of nine teachers at four schools. In addition, it excluded the voices of senior management teams regarding their perceptions of teacher leadership.

\section{Recommendations}

This paper recommends that senior management team members' thoughts regarding teacher leadership development in schools should be put under the spotlight from a performative narrative point of view. We also recommend that action research be conducted to test the implementation of the proposed CTLDF in schools.

\section{References}

Amri, M., Angelakis, C., \& Logan, D. (2021). Utilizing asynchronous email interviews for health research: Overview of benefits and drawbacks. BMC Research Notes, 14, 15. https://doi.org/10.1186/s13104-021-05547-2

Angelle, P. S. (2017). Leading beyond the classroom. International Studies in Educational Administration (Commonwealth Council for Educational Administration $\mathcal{E}$ Management), 45(3), 101-107.

Baker-Doyle, K. J. (2017). Transformative Teachers: Teacher Leadership and Learning in a Connected World. Harvard Education Press.

Behrstock-Sherratt, E., Brookins, P., \& Payne, G. (2020). Teacher leadership in uncertain times: Recommendations from board-certified teachers for school, district and state leaders. https://www.nbpts.org/wp-content/uploads/Covid-Teacher-Leadership.pdf

Berg, J. H., Horn, P., Supovitz, J. A., \& Margolis, J. (2019). Typology of teacher leadership programs. CPRE Research Rorts. https://repository.upenn.edu/cpre_researchreports/109

Berg, J. H., \& Zoellick, B. (2019). Teacher leadership: Toward a new conceptual framework. Journal of Professional Capital and Community, 4(1), 2-14. https:// doi.org/10.1108/JPCC-06-2018-0017

Bowker, N., \& Tuffin, K. (2004). Using the online medium for discursive research about people with disabilities. Social Science Computer Review, 22, 228-241. https:// doi.org/10.1177/0894439303262561

Case, P., French, R., \& Simpson, P. (2011). Philosophy of leadership. In A. Bryman, D. Collinson, K. Grint, B. Jackson \& M. Uhl-Bien (Eds.), SAGE Handbook of Leadership (pp. 685-727). Sage.

Cheung, R., Reinhardt, T., Stone, E., \& Little, J. W. (2018). Defining teacher leadership: a framework. Phi Delta Kappan, 100(3), 38-44. https://doi.org/10.1177/0031721718808263

Chikoko, R. (2015). Emerging professional teacher identity of early childhood development/ foundation phase pre-service teachers: An interplay of dispositions. [Unpublished Ph.D. thesis, University of KwaZulu-Natal]. http://ukzn-dspace.ukzn. ac.za/handle/ 10413/13928

Clandinin, D. J., \& Connelly, F. M. (2000). Narrative inquiry: Experience and story in qualitative research. Jossey Bass.

Costello, L., McDermott, M.-L., \& Wallace, R. (2017). Netnography: Range of practice, misperceptions, and missed opportunities. International Journal of Qualitative Methods, 16, 1-12. http:// doi.org/10.1177/1609406917700647 
De Klerk, E. D. (2014). Teacher autonomy and professionalism: A policy archaeology perspective. [PhD dissertation, Stellenbosch University].

De Klerk, E. D., \& Smith, N. (2021). Transformative intervention strategies for teacher leaders during the pandemic and beyond. International Journal of Learning, Teaching and Educational Research, 20(9), 52-67. https://doi.org/10.26803/ijlter.20.9.4

Drago-Severson, E. \& Blum-DeStefano, J. (2018). Leading change together: Developing educator capacity within schools and systems. ASCD.

Education Development Trust. (2020a). Learning Renewed: A safe way to reopen schools in the Global South. https://www.educationdevelopmenttrust.com/our-research-andinsights/commentary/learning-renewed-a-safe-way-to-reopen-schools-in-t

Education Development Trust. (2020b). Key lessons on effective leadership during COVID-19 and beyond. https://www.educationdevelopmenttrust.com/our-research-andinsights/commentary/key-lessons-on-effective-leadership-during-covid-1

Fairman, J. C., \& Mackenzie, S. V. (2014). How teacher leaders influence others and understand their leadership. International Journal of Leadership in Education: Theory and Practice, 2014, 1-27. https://doi.org/10.1080/13603124.2014.904002

Foucault, M. (1983). Discourse and Truth: The Problematization of Parrhesia (six lectures given by Michel Foucault). University of California, October-November 1983.

Gergen, K. (2015). An invitation to social construction (3rd ed.). Sage.

Gratacós, G., De Guevara, B. L., \& Rodriguez, I. (2021). A study of teacher leadership concept in institutional documents in Spain. Research in Educational Administration E Leadership, 6(1), 241-275. https://doi.org/10.30828/real/2021.1.8

Halpren, E.S. (1983). Auditing naturalistic inquiries: The development and application of a model. [PhD dissertation, Indiana University].

Harris, A., \& Jones, M. (2019). Teacher leadership and educational change. School $\begin{array}{llll}\text { Leadership } \quad \text { E } & \text { Management, } & 39(2), & 123-126 .\end{array}$ https://doi.org/10.1080/13632434.2019.1574964

Harris, A., \& Jones, M. (2020). COVID 19 - school leadership in disruptive times. School $\begin{array}{llll}\text { Leadership } \mathcal{E} \quad \text { Management, } & \text { 243-247), }\end{array}$ https://doi.org/10.1080/13632434.2020.1811479

Holloway, I., \& Todres, L. (2003). The status of method: Flexibility, consistency and coherence. Qualitative Research, 3, 345-357. https://doi.org/10.1177/1468794103033004

Illingworth, N. (2006). Content, context, reflexivity and the qualitative research encounter: Telling stories in the virtual realm. Sociological Research Online, 11(1), 62-73. http://www.socresonline.org.uk/11/1/illingworth.html

James, N. (2016). Using email interviews in qualitative educational research: Creating space to think and time to talk. International Journal of Qualitative Studies in Education, 29(2), 150-163. https://doi.org/10.1080/09518398.2015.1017848

Johnson, S. M. (2019). Where teachers thrive: Organizing schools for success. Harvard Education Press.

Kamaruzaman, N. L., Musa, K., \& Hashim, Z. (2020). Teacher leadership: Concept and framework. International Journal of Academic Research in Progressive Education and Development, 9(2), 574-587. https://doi.org/10.6007/IJARPED/v9-i2/7628

Kozulin, A. (1990). Vygotsky's Psychology: A Biography of Ideas. Harvard University Press.

Landa, J. B., \& Donaldson, M. L. (2020). Teacher leadership roles and teacher collaboration: Evidence from Green Hills public schools Pay-for-Performance System. Leadership and Policy in Schools, 2020, 1-26. https://doi.org/10.1080/15700763.2020.1759648 
Lester, L. (1999). An introduction to phenomenological research. https://www.researchgate.net/publication/255647619_An_introduction_to_ph enomenological_research

McGonigal, K. (2015). The upside of stress: Why stress is good for you, and how to get good at it. Penguin.

Meho, L. I. (2006). E-mail interviewing in qualitative research: A methodological discussion. Journal of the American Society for Information Science and Technology, 57(10), 1084-1095. https://doi.org/10.1002/asi.20416

Mezirow, J. (2000). Learning to think like an adult: Core concepts of transformation theory. In J. Mezirow \& Associates (Eds.), Learning as Transformation (pp. 334). Jossey-Bass.

Mezirow, J. (2011). Transformative learning theory. In J. Mezirow \& E. W. Taylor (Eds.), Transformative Learning in Practice: Insights from Community, Workplace, and Higher Education (pp. 18-32). John Wiley \& Sons.

Mezirow, J. (2012). Learning to think like an adult: Core concepts of transformative theory. In E.W. Taylor \& P. Cranton, P. (Eds.). The Handbook of Transformative Learning: Theory, Research, and Practice (pp. 5-15): John Wiley \& Sons.

Mitchell, T. L. (2021). Developing teacher leadership during unprecedented times of change. [D.Ed. dissertation, Kansas State University].

Mogashoa, T. (2014). Applicability of constructivist theory in qualitative educational research. American International Journal of Contemporary Research, 4(7), 51-59. http://www.aijcrnet.com/journals/Vol_4_No_7_July_2014/7.pdf

Nieuwenhuis, J. (2017). Analysing qualitative data. In K. Maree (Ed.), First steps in research (pp. 104-130). Van Schaik.

Organisation for Economic Co-operation and Development. (2020). TALIS 2018 results (Volume II): Teachers and school leaders as valued professionals. TALIS, OECD Publishing. Retrieved from http://www.oecd.org/education/talis-2018-resultsvolume-ii19cf08df-en.htm

Pandey, M., \& Pandey, P. (2015). Research methodology: Tools and techniques. Bridge Center.

Pasetto, S. C., Barreiros, J. M. P., Corrêa, U. M., \& Freudenheim, A. M. (2021). Students' perceptions of collaborative team teaching and student achievement motivation. International Journal of Instruction, 14(1), 325-344. https://doi.org/10.29333/iji.2021.14119a

Patton, M.Q. (2015). Qualitative research \& evaluation methods: Integrating theory and practice (4th ed.). Sage.

Pouliot, V. (2007). Subjectivism: Toward a constructivist methodology. International Studies Quarterly, 51, 359-384. https://www.jstor.org/stable/4621718

Qutoshi, S. B. (2018). Phenomenology: A philosophy and method of inquiry. Journal of Education and Educational Development, 5(1), 215-222. https://files.eric.ed.gov/fulltext/EJ1180603.pdf

Smith, L., \& Riley, D. (2012). School leadership in times of crisis. School Leadership $\mathcal{E}$ Management, 32(1), 57-71. https:// doi.org/10.1080/13632434.2011.614941

Speziale, H. J., \& Carpenter, D. R. (2007). Qualitative research in nursing: Advancing the humanistic imperative (4th ed.). Williams and Wilkins.

Taylor, C. (1989). Sources of the self. Harvard University Press.

Thomas, A., Menon, A., Boruff, J., Rodriguez, A. M., \& Ahmed, S. (2014). Applications of social constructivist learning theories in knowledge translation for healthcare professionals: A scoping review. Implementation Science, 9(54), 1-20. http://www.implementationscience.com/content/9/1/54 
Vicente, A. J., Tan, T. A., \& Yu, A. R. (2018). Collaborative approach in software engineering education: An interdisciplinary case. Journal of Information Technology Education: Innovations in Practice, 17, 127-152. https://doi.org/10.28945/4062

Wilson, A. (2021). Emotionally agile leadership amid COVID-19. School Leadership Review, 15(2), 1-21. https://scholarworks.sfasu.edu/slr/vol15/iss2/1

Yin, R. K. (2011). Qualitative research from start to finish. Guilford Press.

Zhang, M., Tian, J., Ni., H., \& Fang. G. (2021). Exploring teacher leadership and the factors contributing to it: An empirical study on Chinese private higher education institutions. SAGE Open, 11(1), 1-12. https://doi.org/10.1177/21582440211002175

\section{Appendix 1 \\ Email interview grid on teachers' perceptions about teacher leadership}

\begin{tabular}{|l|l|}
\hline $\begin{array}{l}\text { Purpose of the } \\
\text { study }\end{array}$ & $\begin{array}{l}\text { To apply transformative learning to invest in knowledge } \\
\text { acquisition regarding teacher leadership in schools with } \\
\text { specific reference to collaborative teacher leadership }\end{array}$ \\
\hline
\end{tabular}

1. Why do you think, it is important that teachers are developed as teacher leaders in schools?

2. In your opinion, wat are the contributions that teachers as leaders can make to education and the school environment in particular?

3. How would you describe a teacher leader? Please elaborate on the specific characteristics you deem necessary that a teacher leader should possess.

4. Why do you think it is important to motivate teachers to participate in professional learning activities? Would you regard it as fundamental? Please motivate.

5. Can you tell me more about your leadership experience before and during the COVID-19 pandemic? Which duties were you entrusted with? Describe your reactions, fears, approaches etc.

6. How will you demonstrate that you consistently listen to the people affected by your efforts?

7. How would you as teacher leader collaborate with your colleagues to improve the learner academic achievement in your school? Please cite examples if possible.

8. How would you assist a colleague who is having difficulty with his/her teaching?

9. What would you consider to be some of the best methods to use to achieve the educational goals set by policy groups (e.g. department of education).

10. Would you regard mentoring as a part of your responsibility as a professional teacher? Motivate why you say so. 